\title{
Determination of Inflation in an Open Economy Phillips Curve Framework: The Case of Developed and Developing Asian Countries
}

\author{
Pami Dua \\ Email: dua@econdse.org \\ Department of Economics \\ Delhi School of Economics \\ University of Delhi \\ Upasna Gaur \\ Global Research Group, ICICI Bank \\ Mumbai
}

Working Paper No. 178 


\title{
Determination of Inflation in an Open Economy Phillips Curve Framework: The Case of Developed and Developing Asian Countries
}

\author{
Pami Dua ${ }^{1}$ \\ Department of Economics \\ Delhi School of Economics \\ University of Delhi, Delhi 110007 \\ and \\ Upasna Gaur \\ Global Research Group, ICICI Bank \\ Mumbai
}

April 2009

\begin{abstract}
This paper investigates the determination of inflation in the framework of an open economy forward-looking as well as conventional backward-looking Phillips curve for eight Asian countries - Japan, Hong Kong, Korea, Singapore, Philippines, Thailand, China Mainland and India. Using quarterly data from the 1990 s to 2005 and applying the instrumental variables estimation technique, we find that the output gap is significant in explaining the inflation rate in almost all the countries. Furthermore, at least one measure of international competitiveness has a statistically significant influence on inflation in all the countries. The differences in the developed and developing world are highlighted by the significance of agriculture related supply shocks in determining inflation in the case of developing countries. For all countries, the forward-looking Phillips curve provides a better fit compared to the backward looking variant.
\end{abstract}

\section{Acknowledgments}

Earlier versions of this paper were presented at the Project LINK Meeting in October 2006 at United Nations, Geneva; at IGIDR, Mumbai in the $10^{\text {th }}$ Annual Conference on Money and Finance in January, 2008 and at the Conference on Growth and Macroeconomic Issues and Challenges in India at the Institute of Economic Growth in February, 2008. The authors are grateful to the participants of these meetings for useful comments.

\footnotetext{
${ }^{1}$ Corresponding author, e-mail address: dua@econdse.org
} 


\section{Introduction}

The Asian continent is the most diverse region in the world which, on the one hand, has one of the most developed countries in the world, viz. Japan, and while on the other, has several least developed countries, such as Nepal, Afghanistan, Bangladesh and Bhutan. The newly industrialized countries and emerging economies in transition also form part of this region.

Most of the Asian emerging economies have sustained high and rapid economic growth in the past one or two decades leading to moderate to high inflation. Inflation has thus become an important concern for the emerging economies.

The dynamics of inflation can be explained in two ways. One school of thought believes that inflation is largely influenced by non-monetary factors such as supply shocks, which somewhat obscures the role of demand side factors and hence the monetary transmission mechanism in the inflation process. The other school of thought argues that nonmonetary factors affect only the short-run path of inflation while in the long-run, monetary variables determine the inflation rate. As a result, it is argued that the standard output gap model of the Phillips curve should offer a reasonable explanation of the inflation dynamics in emerging market economies. However, given the diversity amongst nations in Asia, inflation should be treated as a country-specific phenomenon, the determinants of which would differ across countries. Thus, it is crucial to investigate the plausible distinct factors that determine inflation in various nations.

Against this backdrop, we attempt to empirically determine the factors affecting inflation in an open economy Phillips curve framework for eight Asian countries - Japan, Korea, Hong Kong, Singapore, Philippines, Thailand, China, and India. These countries contribute about $80 \%$ of the total Asian GDP as shown in Table 1. The region-wise share of each of these countries is shown in Table 2.

Each nation is characterized by diverse socio-economic conditions. For instance, the share of agriculture in GDP ranges from $0.05 \%$ in Hong Kong in 2005 to approximately $20 \%$ in India. The share of labor force employed in agriculture also varies from $0.12 \%$ in Singapore in 2005 to $56 \%$ in India. Further, the share of imports in GDP also range from as low as $11 \%$ in Japan in 2005 to as high as $188 \%$ in Philippines (see Tables 4 and 5). Despite their diverse characteristics, we can broadly classify them on the basis of different stages of development as developed (major industrialized economy or newly industrialized economy) or developing economies (Table 2). 
In order to determine the drivers of inflation in an open economy setup, we investigate the importance of the demand and supply side measures for each of these eight Asian countries. We also analyze whether the estimated relationship should be forward looking with the expected inflation rate included as an independent variable, or backward looking. Several studies have been conducted for the developed economies (e.g. Fuhrer and Moore, 1995; Gali and Gertler, 1999; Batini et. al, 2000; Rudd and Whelan, 2005) that focus on a forward looking Phillips Curve. This paper evaluates the possibility of a forward looking Phillips curve for the developing nations as well.

The remainder of the paper is structured as follows. The next section provides the theoretical framework that is applied to our study and the plausible determinants of inflation. Section 3 provides the data and methodology used in our study. Section 4 presents the estimation results. Section 5 gives the conclusions of our study.

\section{The Model}

Since the focus of the paper is on the determination of inflation within the framework of a Phillips curve, the ensuing discussion briefly describes the theoretical foundations of the Phillips curve. The traditional Phillips curve, which provided empirical evidence of a tradeoff between unemployment gap and wage inflation, has undergone considerable modifications. Theoretical foundations of the new Phillips curve emphasize the role of expectations. Specifically, the New Keynesian Phillips Curve (NKPC) incorporates forward looking behaviour of inflation (see e.g. Fuhrer and Moore, 1995; Roberts, 1995; Fuhrer, 1997; Yun, 1996; Goodfriend and King, 1997; Clarida et al., 1999; Gali and Gertler, 1999; Batini et al., 2000; Svensson (2000); Jensen, 2002; Mankiw and Reis, 2002; Woodford, 2003; Gali, Gertler and Lopez-Salido, 2005; Rudd, J. and Whelan K., 2005).

The new Phillips curve follows the staggered contract model of Taylor ${ }^{2}$ (1980) and Calvo (1983) with sticky nominal wages and prices in a set-up with forward-looking agents. According to the NKPC analysis, the agents optimize rationally their wage-setting and pricemaking decision inter-temporally. However, there are nominal rigidities within the economy that do not allow them to adjust wages and prices immediately as shocks occur. These rigidities give rise to the trade-off between inflation and excess demand in the short run, which in turn opens a channel through which monetary policy can affect real variables.

\footnotetext{
${ }^{2}$ In Taylor (1980), the staggered price adjustment process is deterministic, while in Calvo (1983) the staggered price adjustment behaviour is stochastic.
} 
Following the NKPC model, the framework for examining inflation in the context of a general backward looking Phillips curve takes the form:

$$
\pi_{t}=\alpha+\sum_{i=1}^{n} \beta_{i} \pi_{t-1}+\sum_{i=1}^{n} \gamma_{i} D_{t}+\sum_{i=1}^{n} \lambda_{i} X_{t}+\sum_{i=1}^{n} \psi_{i} Z_{t}+\sum_{i=1}^{n} \phi_{i} T_{t}+\varepsilon_{t}
$$

Likewise, the framework for examining inflation in the context of a general forward looking Phillips curve is as follows

$$
\pi_{t}=\alpha+\beta E_{t}\left[\pi_{t+1}\right]+\sum_{i=1}^{n} \gamma_{i} D_{t}+\sum_{i=1}^{n} \lambda_{i} X_{t}+\sum_{i=1}^{n} \psi_{i} Z_{t}+\sum_{i=1}^{n} \phi_{i} T_{t}+\varepsilon_{t}
$$

where $\pi$ denotes inflation rate, $\mathrm{E}$ is the expectations operator, $\mathrm{D}$ denotes domestic demand side factors, $\mathrm{X}$ represents external demand side factors, $\mathrm{Z}$ represents domestic supply side factors and $\mathrm{T}$ represents external supply side factors.

Depending on the specific stage of development, countries have varying characteristics which can impact inflation. While we do not cover an exhaustive list of determinants ${ }^{3}$, we do attempt to include factors which are potentially important in determining inflation in an open economy framework. These can be broadly divided into the following categories:

Demand factors: Demand factors can be further sub-divided into domestic and external factors.

\section{Domestic factors (D)}

In the case of most Phillips Curve models for developed countries, the output gap has been applied as an indicator of demand. The link between interest rate and excess demand is found to be strong in the case of developed economies because of which the transmission mechanism from monetary policy to the real economy (via the interest rate) is expected to be effective. It has therefore been argued that money should not be included in the Phillips curve along with output gap since the impact of money on aggregate demand is captured through its effect on the interest rate (Scheibe and Vines, 2005). Output gap models of inflation, however, have been less commonly applied in the case of developing countries. Coe and

\footnotetext{
${ }^{3}$ Mohanty and Klau (2001) discuss in detail the literature available on the possible determinants of inflation in case of emerging economies.
} 
McDermott (1997) in a study of the output gap model in Asia found that this model did not work well for Thailand, China and India.

One explanation for this is that developing countries have relatively underdeveloped financial markets, and therefore a weak relationship exists between interest rates and aggregate demand. Hence, for developing countries, the real money gap can be taken as a potential determinant of inflation in addition or in lieu of the output gap.

In this study, domestic demand factors are therefore captured both by the output gap and the real money gap.

\section{External factors $(X)$}

The role of the exchange rate in determining inflation has been emphasized extensively in the literature. The exchange rate has a direct impact on the price of imports as well as an overall impact on prices through transmission of higher prices and inflation expectations. Ho and McCauley (2003) suggest that the significance of the exchange rate in the evolution of domestic inflation tends to be greater in the case of emerging market economies as compared to the developed economies. Ito and Sato (2006) show that the exchange rate is statistically significant in determining inflation in Korea and Thailand but insignificant in the case of Singapore.

In this paper, the nominal exchange rate and import inflation are included as measures that indicate competitiveness of a nation on the demand side.

Supply factors: Supply factors can be further sub-divided into domestic and external factors.

\section{Domestic factors (Z)}

Domestic supply shocks, especially with respect to the agricultural sector, can have major macroeconomic implications for developing countries. Regardless of whether the shock is temporary or permanent, the extent of the impact on inflation depends on the weight of the affected sector in consumer prices. For instance, in developing countries food has a relatively large share in the consumer price index (CPI). Furthermore, food prices tend to be volatile owing to the influence of weather and the presence of trade barriers. Thus, an increase in the price of food commodities not only raises short-run inflation owing to their high weight in CPI, but can also engender a sustained increase in the inflation rate via inflationary expectations.

In this study, several measures are used to capture the supply side effects on inflation -- food inflation, percentage change in index of food production, rainfall and the differential between wage inflation and productivity growth per worker. 


\section{External factors (T)}

Energy consumption forms a relatively large share in the CPI consumption basket in several countries. Most of the emerging economies have administered energy prices. However, these economies have faced inflationary pressures over different periods owing to liberalisation of administered prices. Thus, whether administered prices cause inflation or not depends on the nature of price adjustments. If administered prices are revised periodically to restore their relative level, they may not affect average inflation (Mohanty and Klau, 2001).

To account for external supply shocks, global oil prices are included as a supply-side external variable.

\section{Data and Methodology}

Quarterly data is used for the estimation of the open economy Phillips Curve for each country (equations 1 and 2). Data for most of the variables has been taken from the International Monetary Fund's International Financial Statistics (IFS) database and the World Development Indicators database.

We consider a stylized model with alternative specifications for the expected inflation rate (see equations 1 and 2). The dependant variable is the annualized inflation rate calculated using the Consumer Price Index. The expected inflation for a backward looking Phillips is estimated using last period's inflation ${ }^{4}$. Four estimation specifications for forward-looking expectations are employed - naïve forecast, perfect foresight, ARIMA ${ }^{5}$ (one quarter ahead and four quarter ahead forecast) and a measure of core inflation ${ }^{6}$. Core inflation has been calculated using the exponential smoothing technique. These models are illustrated below for one period ahead forecast:

$$
\begin{array}{ll}
\text { Backward looking forecast: } & \pi^{\mathrm{e}}=\pi_{\mathrm{t}-1} \\
\text { Naïve forecast: } & { }_{\mathrm{t}} \pi^{\mathrm{e}}{ }_{\mathrm{t}+1}=\pi_{\mathrm{t}} \\
\text { Perfect foresight: } & { }_{\mathrm{t}} \pi^{\mathrm{e}}{ }_{\mathrm{t}+1}=\pi_{\mathrm{t}+1}
\end{array}
$$

\footnotetext{
${ }^{4}$ In the case of emerging economies where expectation formation is likely to be more difficult than in developed economies, it has usually been believed that a backward-looking Phillips curve would be more suitable.

${ }^{5}$ Forecasts are made recursively by continuously updating and re-estimating the model starting from 1980 Q1. The drawbacks of using a univariate approach to forecasting are well known.

6 The estimates of core inflation in many countries are based on the wholesale price index (WPI) using the weights of different components of WPI. For instance, for India, the exclusion method, limited influence method, a common trends model or a structural VAR approach have been applied to measure core inflation (see Durai and Ramachandran, 2007; Goyal and Pujari, 2005), but these employ WPI only. In this study, we use aggregate CPI as a measure of inflation uniformly for all the countries and investigate the possibility of 2-4 quarter moving average estimates and single and double exponential smoothing techniques.
} 
ARIMA (p,d,q) model: $\quad \varphi(\mathrm{L})(1-\mathrm{L})^{\mathrm{d}} \pi_{\mathrm{t}}=\delta+\theta(\mathrm{L}) \varepsilon_{\mathrm{t}}$

where $\mathrm{L}=$ backward shift operator

$\varphi(\mathrm{L})=$ autoregressive operator $=1-\varphi_{1} \mathrm{~L}-\varphi_{2} \mathrm{~L}^{2}-\ldots \ldots \ldots-\varphi_{\mathrm{p}} \mathrm{L}^{\mathrm{p}}$

$\theta(\mathrm{L})=$ moving average operator $=1-\theta_{1} \mathrm{~L}-\theta_{2} \mathrm{~L}^{2}-\ldots \ldots . \theta_{\mathrm{q}} \mathrm{L}^{\mathrm{q}}$

The measures of core inflation are obtained as follows:

Moving average: $\quad{ }_{\mathrm{t}} \pi^{\mathrm{e}}{ }_{\mathrm{t}+\mathrm{l}}=1 / \mathrm{k} \Sigma \pi_{\mathrm{i}}$

where $\mathrm{i}=\mathrm{t}-\mathrm{k}+1$ through $\mathrm{t}$

Single exponential smoothing: ${ }_{\mathrm{t}} \pi^{\mathrm{e}}{ }_{\mathrm{t}+1}=\alpha \pi_{\mathrm{t}}+(1-\alpha)_{\mathrm{t}-1} \pi_{\mathrm{t}}^{\mathrm{e}}$

where $\alpha$ is a smoothing coefficient between 0 and 1 .

Double exponential smoothing (Holt's method):

$$
\begin{aligned}
& \mathrm{S}_{\mathrm{t}}=\alpha \pi_{\mathrm{t}}+(1-\alpha)\left(\mathrm{S}_{\mathrm{t}-1}+\mathrm{T}_{\mathrm{t}-1}\right) \\
& \mathrm{T}_{\mathrm{t}=}=\beta\left(\mathrm{S}_{\mathrm{t}}-\mathrm{S}_{\mathrm{t}-1}\right)+(1-\beta) \mathrm{T}_{\mathrm{t}-1} \\
& { }_{\mathrm{t}} \pi^{\mathrm{e}}{ }_{\mathrm{t}+1}=\mathrm{S}_{\mathrm{t}}+\mathrm{T}_{\mathrm{t}}
\end{aligned}
$$

where $S_{t}=$ equivalent of single exponential smoothed value

$\mathrm{T}_{\mathrm{t}}=$ smoothed trend in data series

$\beta$ and $\alpha$ are smoothing coefficients

In the special case where $\alpha=\beta$, the method is equivalent to Brown's double exponential smoothing.

To measure the output gap, we use the Hodrick-Prescott (HP) filter (with a smoothing coefficient of 1600) to de-trend the data ${ }^{7}$. The HP filter decomposes actual output into a longrun trend and cyclical components and hence provides a useful approximation of potential output growth. Similarly, real money gap is also calculated using the HP filter. Money gap for each country is calculated using the M2 or M3 measure of monetary aggregate, deflated by the consumer price index.

\footnotetext{
${ }^{7}$ Although we do recognize that potential output might vary due to real disturbances, which cannot be captured by simply smoothing the series, due to unavailability of sufficient data we use the HP filter method to segregate the cyclical part from the data.
} 
The impact of exchange rate movements on inflation has been analyzed by including changes in the nominal exchange rate defined as domestic currency per US dollars, such that any increase in the nominal exchange rate corresponds to depreciation of the domestic currency.

Import inflation is calculated using the quarterly unit value index of imports. The data for this is taken from International Financial Statistics. Oil inflation is based on the quarterly log difference of world oil prices, as taken from Energy Information Administration's (EIA) Monthly Energy Review. The data for the food production index and food prices have been taken from World Development Indicators, 2007. The data for productivity of workers in the case of China has been taken from Holz (2006). The data for rainfall in India has been taken from India's Meteorological Department.

To test if the series are non-stationary or contain a unit root, we focus on the augmented Dickey-Fuller (ADF) test $(1979,1981)$, the Phillips-Perron (PP) test (1988) and the KPSS test proposed by Kwiatkowski et al. (1992). If two of these three tests indicate nonstationarity for any series, we conclude that the series has a unit root. We find that almost all the series have a unit root $^{8}$.

Since the output gap, expected inflation and change in exchange rate are considered to be endogenous variables, the Wu-Hausman test (1978) for consistency of OLS was carried out. In almost all the cases the null hypothesis of consistency of OLS was rejected. Hence we employ the IV method to estimate both the backward looking and forward-looking Phillips curve.

Moreover, Hsiao (1997) has shown that even if the variables are non-stationary, the standard IV Estimation methods and testing procedures can still be applied, provided the variables are cointegrated. If endogenous variables are treated as those determined by the model and exogenous variables as independently determined, then presence/absence of cointegration is pre-assumed from the way a structural model is set up. Thus we employ the standard techniques of estimation in our study.

The additional instruments considered in our analysis include lagged variables of all the endogenous variables (output gap, expected inflation, nominal exchange rates) and other exogenous variables (import inflation, oil inflation, gap between wage inflation and productivity growth rate, growth rate of money supply, food production index, food prices and long-run interest rates).

\footnotetext{
${ }^{8}$ The tests for unit root are not reported for the sake of brevity.
} 
To test for the validity of the instruments used in the models we conducted the test of over identified restrictions (Sargan, 1958). This is an asymptotic test of the validity of the choice of instrumental variables and of the over identifying restrictions implied by excluding the additional explanatory variables from the estimated equation. Under the null hypothesis, the test statistic is asymptotically distributed as $\chi_{m-k}^{2}$ where $\mathrm{m}$ is the number of instruments and $\mathrm{k}$ is the number of explanatory variables.

To test for serial correlation in the IV set up, we conduct the Lagrange Multiplier test (Bean, 1981 and Gugnani, 1985), with the null hypothesis of white noise errors against the alternative of up to $p$ th order autocorrelation. This test yields a statistic which is asymptotically distributed as $\chi_{p}^{2}$.

A test for structural change in 1998Q1 was performed to check if the East Asian crisis resulted in a structural break. A Wald test is used to test for structural break under IV estimation since the Chow test is not valid ${ }^{9}$. For this, an appropriate instrument set is formed which includes the dummies corresponding to the intercept and explanatory variables ${ }^{10}$. Under the null hypothesis of no structural change, the coefficients of the dummy variables in an IV regression should be statistically insignificant. The test statistic can be shown to be asymptotically distributed as $\chi_{m}^{2}$, where $\mathrm{m}$ is the number of dummy variables.

\section{Empirical Estimates}

The empirical estimations are conducted using quarterly data over the following time periods:

$\begin{array}{ll}\text { Japan: } & 1993-2005 \\ \text { Korea: } & 1993-2005 \\ \text { Hong Kong: } & 1993-2005 \\ \text { Singapore: } & 1997-2005 \\ \text { Philippines: } & 1992-2005 \\ \text { Thailand: } & 2001-2005 \\ \text { China: } & 2000-2005 \\ \text { India: } & 1996-2005\end{array}$

\footnotetext{
${ }^{9}$ In IV estimation, the total sum of squares cannot be partitioned into explained and unexplained sum of squares since the residuals obtained by substituting the IV estimates back into the original equation are not orthogonal to all the explanatory variables. Hence the Chow test based on residuals from the equations for the whole sample period and those for the sub-periods is no longer valid (Gugnani, 1985).

${ }^{10}$ For this, additive and multiplicative dummies which allow for changes in the intercept and the coefficients of the explanatory variables respectively are included. These dummies take the value zero in the first period and the actual values in the second sub-period.
} 
Figures 1 and 2 show the scatter plots of the countries under consideration in the inflation-output gap space. The plots in Figure 1 clearly show the existence of a positive relationship for the developed countries. However, the picture is not very clear in the case of developing countries as shown in Figure 2 (see column 2 and 3 of Table 7). In the case of Thailand and China, there is a positive relationship between inflation and output gap but no specific pattern is found in Philippines and India. This variation can probably be attributed to the unique characteristics of the developing economies as against the developed economies. For instance, as shown in Table 4, in the developing countries, the percentage share of agriculture in GDP as well as the percentage employed in the agricultural sector is high. This implies that developing economies are more likely to be vulnerable to agriculture related supply shocks. The relation between inflation and aggregate demand may therefore be marred by such effects.

We therefore attempt to analyze the factors determining inflation in an open economy Phillips curve set-up by accounting for factors in addition to the output gap that are related to the different stages of development of the countries under study.

Results from estimating the inflation models for the developed and developing countries are reported in Tables 6 and 7 respectively. Each table contains results for IV estimates in the case of both backward-looking and forward-looking inflation models ${ }^{11}$.

\section{Estimation Results for Asian Developed Countries}

Considering Table 6, we find that in the case of developed countries, the coefficient of output gap has the expected positive sign (column 7). All the coefficients are significant at the $5 \%$ or $10 \%$ level. This shows that for developed countries, output gap as a measure of aggregate demand is a significant determinant of the inflation rate.

The expected inflation is also statistically significant at the $1 \%$ level of significance in both the backward and forward-looking Phillips Curve for all the developed countries (see columns 2, 3 and 4 of Table 6). The only exception is the core inflation estimate for Hong Kong. The four-period-ahead expected inflation from the ARIMA model yields a better fit in all cases relative to one-period-ahead and is therefore employed in all estimations ${ }^{12}$.

It is also important to note that at least one external variable appears as a significant determinant of inflation. As seen from Table 3, Korea and Japan follow a flexible exchange

\footnotetext{
${ }^{11}$ OLS estimation was also conducted for each country and we generally obtained similar results.

${ }^{12}$ For expected inflation, we report the results for ARIMA forecasts and core inflation only since these almost consistently perform better than naïve and perfect foresight expectations. For the sake of brevity, the results for the latter two are not reported.
} 
rate regime where their exchange rates have depreciated overtime (see Table 4). In both of these countries, we find the exchange rate to be statistically significant and positively influencing inflation (column 8, Table 6). These results are therefore similar to those reported by Ito and Sato (2006).

Unlike, Japan and Korea, imports constitute a large share of GDP in Hong Kong that has increased over time from $134 \%$ in 1995 to $143.5 \%$ in 2005 (see Table 4). Hence, we find import inflation to be positive and statistically significant for Hong Kong (column 9, Table $6)$.

The trade driven Singapore economy is highly dependent on external demand, which has contributed on average about 80 per cent of total demand growth between 1990 and 2005 . Singapore, being a major centre of oil refinery, is a major exporter of petroleum products. It is, however, heavily dependant on crude oil imports since it does not have any natural resources. Thus, oil price shocks affect economic activity in Singapore. This impact is mainly transmitted through higher energy and related costs, which are passed on to output prices and thus consumer price inflation. It is this channel that is captured in our model. Oil price shocks are found to positively affect inflation (see column 10, Table 6).

Since the role of agricultural sector is minimal in the case of developed countries (see Table 4) we do not expect agriculture related supply shocks to impact domestic inflation and therefore did not account for this effect on inflation in the estimations.

Diagnostic tests are conducted for the various countries to ascertain the stability and robustness of the estimation results. These include a test for structural change, serial correlation and over identifying restrictions.

The test for structural change is conducted to examine the impact of the East Asian crisis of 1997 on the estimated results. From Table 6 (column 14) we can infer that in the case of Hong Kong there was no structural change during 1998 since we cannot reject the null hypothesis of no structural break at the 5\% level of significance in both the backward and forward looking versions. For Singapore and Korea, due to lack of sufficient observations, the Wald test for structural change cannot be calculated. Nevertheless, a dummy variable is included in the equation for Korea to take into account the hike in inflation during 1998 quarter 1 through 4.

Japan has been an unusual case that witnessed minimal economic growth of $1 \%$ since the early 1990s, as against an extraordinary performance in the three decades prior to this. The weak condition of the economy was reflected in general prices, which declined since the early 1990s, particularly since 1999. Thus, for Japan we construct a dummy that accounts for 
the sustained period of deflation from 1999 onwards. A Wald test for structural change during the Asian crisis for this model shows that the null hypothesis of no structural change cannot be rejected at the $1 \%$ level of significance.

The Lagrange Multiplier test for first order serial correlation is reported in column 12 of Table 6. For all countries and specifications, the null hypothesis of no serial correlation cannot be rejected at the $1 \%$ level of significance. The test for over identifying restrictions is shown in column 13 of Table 6 and indicates that in all the cases we cannot reject the null hypothesis that the instruments are valid at the $1 \%$ level of significance.

In sum, for the four developed Asian countries, there exists a positive and statistically significant relationship between output gap and inflation. The expected inflation rate also appears with a positive (and significant) sign in all cases. The international effect in the four countries is captured by different variables. For Japan and Korea, the exchange rate is statistically significant in determining inflation and has a positive sign indicating that a depreciating currency exerts upward pressure on prices. The external variable in the case of Singapore is oil prices indicating the dependence of the Singapore economy on oil imports. Import inflation is significant in the case of Hong Kong corroborating the high ratio of imports to GDP in the economy. All equations are stable over time and do not exhibit serial correlation.

\section{Estimation Results for Asian Developing Countries}

The results for the developing countries in Asia are shown in Table 7. The coefficient of the output gap has the expected positive sign and is statistically significant in the case of Philippines, China and India (column 4, Table 7). For Thailand, however, we find that instead of the output gap, real money gap ${ }^{13}$ as a measure of aggregate demand is statistically significant and positive for all the specifications. A possible explanation for this is that the transmission channel between the monetary sector and the real sector (aggregate demand) via the interest rate may be weak. Thus, although the output gap should reflect all monetary changes, this may not always happen especially in the case of a developing country with a relatively underdeveloped financial market.

The expected inflation ${ }^{14}$ estimates for Thailand and India are statistically significant at the $5 \%$ level of significance in both the backward looking and forward looking Phillips

\footnotetext{
${ }^{13}$ We also estimated the equation using the growth rate of money supply. However, this was not statistically significant

${ }^{14}$ See footnote 12 .
} 
curves (see column 2 and 3 of Table 7). For Philippines, the core inflation estimate and the backward looking version are significant although the ARIMA estimate is not. In the case of China, only the core inflation measure is statistically significant at the $1 \%$ level. The backward looking version is significant only at the $22 \%$ level. This result is consistent with those reported in Scheibe and Vines (2005). As for developed countries, the four-periodahead expected inflation from the ARIMA model yields a better fit for all developing countries as well relative to one-period-ahead forecasts and is therefore employed in all estimations.

From the external perspective, we find that the change in the nominal exchange rate is statistically significant and positive implying an inflationary impact of depreciation of the exchange rate for all the developing countries (column 5, Table 7). As shown in Table 5, with a free floating exchange rate regime, the exchange rate depreciated from 2000 to 2005 in Philippines and Thailand, while with a managed floating exchange rate regime, it marginally appreciated in China and India.

Unlike the developed countries, the developing countries are heavily dependant on agriculture. Table 5 shows the high percentage of labor force employed in agriculture for each of these countries. These economies are primarily agrarian, even though their share of this sector in GDP has been decreasing overtime. Furthermore, the developing countries have inferior rural infrastructure as compared to the developed countries, which usually tends to aggravate agricultural shortage and hence exert further pressure on prices. Due to heavy dependence of these developing economies on agriculture, we have incorporated different measures of agriculture related supply side shocks to capture the peculiarities of each of these countries. The measures reported here are the ones that gave significant results after experimenting with various alternatives.

Philippines has frequently been a victim of typhoons and is also susceptible to drought. This has made it vulnerable to periodic agricultural shortages and thus agricultural price increases. The impact of these shocks is captured in the model by the rate of growth of the food production index (column 8, Table 7). As expected, we find the food production index to be negatively related to overall inflation. This result conforms to the argument made in $\operatorname{Lim}(2007)$.

In the case of Thailand, food inflation is found to be statistically significant and positive (column 6, Table 7). For China, along with food inflation, a measure of productivity, calculated as the difference between wage inflation and value added per worker, is statistically significant and positively impacts inflation. This is primarily because in China 
wage inflation has been greater than productivity producing an inflationary impact on the economy (columns 6 and 7, Table 7).

India's agricultural sector still continues to be heavily dependant on rainfall with less than $40 \%$ of the land irrigated. Hence we use the deviation of actual rainfall from the average rainfall (as measured by the HP filter) to analyse the impact of agricultural shocks on inflation $^{15}$. We find this measure is statistically significant (column 9, Table 7). Excess or shortage of rainfall results in a reduction in food production, which would in turn cause inflationary pressures.

We find that oil shocks do not seem to affect the overall inflation rate in the case of the developing economies. As pointed out by Mohanty and Klau (2001), since in most of these countries oil prices still continue to be administered and price revisions are staggered, the domestic oil prices may not move in line with the international oil price shocks. It is probably because of this reason we do not find global oil price changes to statistically influence inflation.

The diagnostic tests are also conducted for the developing countries. Due to lack of sufficient observations, the Wald test for structural change for Thailand, China and India cannot be computed. In the case of Philippines, for various specifications of the expected inflation rate, the null hypothesis of no structural change cannot be rejected at the $1 \%$ level of significance.

Column 11 in Table 7 further indicates that there does not exist any serial correlation of order one at the $1 \%$ level of significance for each country. The over identifying restriction test statistic as indicated in column 12 of Table 7 indicates that in all the cases we cannot reject the null hypothesis that the instruments are valid.

To sum up, it is noteworthy that in the case of all these developing countries, demand side shocks can only partially determine inflation. If we do not account for the supply side factors, we find that the output gap does not statistically impact inflation and the equation thus suffers from misspecification. This can also be noted by Figure 2 which indicates a weak relationship between inflation and output gap. This result is found to be consistent with Mohanty and Klau (2001).

\section{Conclusions}

\footnotetext{
${ }^{15}$ We create dummies for deviation where Dummy3 indicates deviation greater than zero and Dummy4 is the deviation less than zero.
} 
In this paper we examine the determination of inflation in the framework of both the backward-looking and forward-looking Phillips curves for eight Asian economies for varying time periods. We generally ${ }^{16}$ find that both forward looking and backward looking inflation expectations play an important role in explaining inflation. In the case of ARIMA based forward-looking expectations, we find that longer term (four-quarter-ahead) inflation expectations give a better fit rather than one-quarter.

Our results clearly point towards the fact that there exists a similar pattern in the variables determining inflation across developed economies. Similarly, we find commonalities across developing countries. These factors are summarized in Table 8. This table also highlights the differences between developing and developed countries.

In the case of developed countries we find that monetary policy may be effective in controlling inflation via the output gap channel. The estimations, however, show that in the developing economies, aggregate demand alone does not determine inflation. In fact, aggregate supply shocks measures are also important determinants of inflation. Since developing economies are heavily dependent on agriculture even today, agricultural supply shocks are key factors that influence domestic inflation. Consequently, policy measures undertaken by the monetary authorities in these countries should focus not only on the demand side but also on the supply side factors.

${ }^{16}$ China is an exception where backward looking expectations are not significant. 


\section{References}

Batini, N, Jackson B, and Nickell S (2000), 'Inflation dynamics and labor share in the UK,' Discussion Paper 2, External MPC unit, Bank of England.

Bean, C. R. (1981), 'Essays in Unemployment and Unanticipated Inflation in Post War Britain,' unpublished Ph.D. thesis, Massachusetts Institute of Technology.

Bhanthumnavin (2002), 'The Phillips curve in Thailand,' presented at the Gorman Workshop Series, Department of Economics, University of Oxford.

Calvo, Guillermo A. (1983), 'Staggered Contracts in a Utility-Maximizing Framework,' Journal of Monetary Economics, 12, 383-98.

Coe D.T and McDermott C.J (1997), 'Does the Gap Model Work in Asia?’ IMF Working Paper No. 69.

Domaç and E. M. Yücel (2005): 'What Triggers Inflation in Emerging Market Economies?' Journal Review of World Economics, 141, 141-164.

Durai S. R. S. and Ramachandran M (2007), 'Core Inflation for India,' Journal of Asian Economics, 18, 365-383.

Fuhrer, J C, (1997), 'The (Un) Importance of Forward-Looking Behaviour in Price Specifications,' Journal of Money, Credit and Banking, 29, 338-50.

Fuhrer, J C and G R Moore (1995), 'Inflation Persistence' Quarterly Journal of Economics, $110,127-59$.

Gali, J and M Gertler (1999), 'Inflation Dynamics: A Structural Econometric Analysis,' Journal of Monetary Economics, 44, 195-222.

Gali J., Gertler M. and Lopez-Salido D (2005), 'Robustness of the Estimates of the Hybrid New Keynesian Phillips Curve,' NBER Working Paper No. 11788. 
Genberg H. and Pauwels L. (2005), 'An Open-Economy New Keynesian Phillips Curve: Evidence From Hong Kong,' Pacific Economic Review,10, 261-277..

Goodfriend, M., and R.G., King (1997), 'The New Neoclassical Synthesis and the Role of Monetary Policy,' In NBER Macroeconomics Annual, edited by B., Bernanke and J., Rotemberg, 231-283.Cambridge, MA: MIT Press.

Goyal, A and Pujari, A.K (2005): 'Analyzing Core Inflation in India: A Structural VAR Approach', Journal of Monetary Economics, 3, 76- 90.

Gugnani, P. (1985), 'An Investigation into the Recent Behaviour of Nominal and Real Interest Rates in the U.K.,' unpublished Ph.D. thesis, London School of Economics.

Ho, C. and R.N. McCauley (2003), 'Living with Flexible Exchange Rates: Issues and Recent Experience in Inflation Targeting Emerging Market Economies', BIS Working Papers, No: 130.

Holz C. A (2006), 'Measuring Chinese Productivity Growth, 1952-2005,' Mimeo. Social Science Division, Hong Kong University of Science and Technology.

Hsiao, C. (1997), 'Cointegration and Dynamic Simultaneous Equations Model,' Econometrica, Econometric Society, 65(3), 647-670.

Ito and Sato (2006), 'Exchange Rate Changes and Inflation in Post-Crisis Asian Economies: VAR Analysis of the Exchange Rate Pass-Through,' NBER Working Papers 12395.

Lim J. (2007), 'A Review of Philippine Monetary Policy Towards An Alternative Monetary Policy,' Economics Department, Ateneo de Manila University.

Lucas, R, JR (1973), 'Some international evidence on inflation output tradeoffs,' American Economic Review, 63, 3, 326-34.

Mankiw N. G. and Reis R. (2003), 'What Measure of Inflation Should a Central Bank 
Target?' Journal of the European Economic Association, MIT Press, 1(5), 1058-1086.

Mohanty, M.S. and Klau M. (2001), 'What Determines Inflation in Emerging Market Countries?' BIS Papers, No. 8, Modeling Aspects of the Inflation Process and Monetary Transmission Mechanism in Emerging Market Countries.

Razzak, W. A. (2002), 'Monetary policy and forecasting inflation with and without the output gap,' Discussion Paper 2002/03, Reserve Bank of New Zealand.

Roberts, J. M. (1995), 'New Keynesian Economics and the Phillips Curve,' Journal of Money, Credit and Banking, 27(4), 975-984.

Rudd, J. and Whelan K. (2005), 'New Tests of the New Keynesian Phillips Curve,' Journal of Monetary Economics, 52(6), 1167-1181.

Sargan, J. D., (1958), 'The Estimation of Economic Relationships Using Instrumental Variables,' Econometrica, 26, 393-415.

Scheibe J. and Vines D. (2005), 'A Phillips curve for China,' Centre for Economic Policy Research Paper.

Svensson, L.E.O. (2000), 'Open economy inflation targeting', Journal of International Economics, 50, 155-183.

Taylor, John B. (1979), 'Staggered Wage setting in a Macro Model,' American Economic Review, 69, 108-13.

— (1980), 'Aggregate Dynamics and Staggered Contracts,' Journal of Political Economy, $88,1-23$.

Woodford, M. (2000), 'Pitfalls of forward looking monetary policy,' American Economic Review, 90, 100-104.

Yun, T. (1996), 'Nominal Price Rigidity, Money Supply Endogeneity and Business Cycles,' Journal of Monetary Economics, 37, 345-370. 
Table 1: Country contribution to Asian GDP

\begin{tabular}{|l|c|}
\hline Country & \% of Asian GDP \\
\hline Japan & 36.6 \\
\hline China & 22.5 \\
\hline India & 7.6 \\
\hline Korea & 7.5 \\
\hline Thailand & 1.7 \\
\hline Hong Kong & 1.6 \\
\hline Singapore & 1.1 \\
\hline Philippines & 1.0 \\
\hline Total & $\mathbf{8 0}$ \\
\hline
\end{tabular}

Source: World Economic Outlook, IMF 2007

Table2: Country Classification

\begin{tabular}{|l|c|c|}
\hline Region & $\begin{array}{l}\text { Region- } \\
\text { wise share } \\
(\%)\end{array}$ & IMF Classification \\
\hline East Asia & 53.56 & Major Industrialised economy \\
\hline Japan & 2.34 & Newly Industrialised economy \\
\hline Hong Kong & 10.96 & Newly Industrialised economy \\
\hline Korea & 32.93 & Developing economy \\
\hline China & 12.6 & Newly Industrialised economy \\
\hline Southeast Asia \\
\hline Singapore & 11.2 & Developing economy \\
\hline Philippines & 19.7 & Developing economy \\
\hline Thailand & 66.4 & Developing economy \\
\hline South Asia
\end{tabular}

Source: World Economic Outlook, IMF 2007 
Table 3: Exchange Rate Regimes in Various Asian Countries

\begin{tabular}{|l|c|}
\hline Country & Exchange rate regime \\
\hline \hline Japan & Free-floating exchange rate \\
\hline Korea & Free-floating exchange rate since 1997 \\
\hline Hong Kong & Currency Board Arrangement \\
\hline Singapore & Managed-float exchange rate \\
\hline Thailand & Free-floating exchange rate since 1997 \\
\hline Philippines & Free-floating exchange rate \\
\hline India & Managed-float exchange rate \\
\hline China & Managed-float exchange rate \\
\hline
\end{tabular}

Source: IMF 2007 
Table 4: Selected Macroeconomic Indicators of Developed Asian Economies

\begin{tabular}{|c|c|c|c|c|c|}
\hline Country & Year & $\begin{array}{l}\% \text { share of } \\
\text { Agriculture in GDP }\end{array}$ & $\begin{array}{l}\% \text { employed in Agricultural } \\
\text { sector }\end{array}$ & $\%$ of imports in GDP & $\begin{array}{l}\text { Exchange rate } \\
\text { (Domestic } \\
\text { currency/USD) }\end{array}$ \\
\hline \multirow[b]{3}{*}{ Japan } & 1995 & 1.900 & 5.700 & 6.393 & 94.060 \\
\hline & 2000 & 1.400 & 5.100 & 8.166 & 107.765 \\
\hline & 2005 & 1.300 & 4.400 & 11.315 & 110.218 \\
\hline \multirow[b]{3}{*}{ Korea } & 1995 & 4.990 & 11.771 & 22.312 & 771.30 \\
\hline & 2000 & 4.325 & 10.602 & 31.366 & 1131.00 \\
\hline & 2005 & 3.519 & 7.941 & 36.997 & 1024.10 \\
\hline \multirow[b]{3}{*}{ Hong Kong } & 1995 & NA & 0.687 & 134.325 & 7.736 \\
\hline & 2000 & 0.070 & 0.312 & 126.101 & 7.791 \\
\hline & 2005 & 0.055 & 0.299 & 143.486 & 7.777 \\
\hline \multirow[b]{3}{*}{ Singapore } & 1995 & 0.177 & 0.217 & 149.740 & 1.417 \\
\hline & 2000 & 0.118 & 0.135 & 145.254 & 1.724 \\
\hline & 2005 & 0.082 & 0.121 & 171.420 & 1.664 \\
\hline
\end{tabular}

Source: IFS database, IMF 2007 and World Development Indicators, 2007

Table 5: Selected Macroeconomic Indicators for Developing Asian Economies

\begin{tabular}{|c|c|c|c|c|c|}
\hline Country & Year & $\begin{array}{l}\% \text { share of } \\
\text { Agriculture in GDP }\end{array}$ & $\begin{array}{l}\% \text { employed in Agricultural } \\
\text { sector }\end{array}$ & $\%$ of imports in GDP & $\begin{array}{l}\text { Exchange rate } \\
\text { (Domestic } \\
\text { currency/USD) } \\
\end{array}$ \\
\hline \multirow[b]{3}{*}{ Philippines } & 1995 & 21.541 & 44.935 & $\overline{55.917}$ & 25.710 \\
\hline & 2000 & 19.784 & 43.412 & 172.936 & 44.190 \\
\hline & 2005 & 19.083 & 36.015 & 187.752 & 55.090 \\
\hline \multirow[b]{3}{*}{ Thailand } & 1995 & 13.550 & 63.333 & 59.952 & 25.59 \\
\hline & 2000 & 9.403 & 46.354 & 82.905 & 24.92 \\
\hline & 2005 & 8.903 & 38.635 & 123.454 & 40.22 \\
\hline \multirow[b]{3}{*}{ China } & 1995 & 18.920 & 52.200 & 16.808 & 4.783 \\
\hline & 2000 & 14.832 & 50.001 & 18.782 & 8.351 \\
\hline & 2005 & 11.384 & 44.801 & 34.502 & 8.194 \\
\hline \multirow[b]{3}{*}{ India } & 1995 & 27.336 & 66.700 & 8.782 & 32.427 \\
\hline & 2000 & 23.895 & 59.945 & 12.381 & 44.942 \\
\hline & 2005 & 19.664 & 56.139 & 23.837 & 44.100 \\
\hline
\end{tabular}

Source: IFS database, IMF 2007 and World Development Indicators, 2007 
Table 6: Estimation Results for the Developed Asian Countries

\begin{tabular}{|c|c|c|c|c|c|c|c|c|c|c|c|c|c|c|c|}
\hline Country & & constant & $\delta^{e} F_{t+4}^{e} \quad \pi_{t}^{\text {core }}$ & $\pi_{t-1}$ & $\begin{array}{c}\pi_{t-2} \text { or } \\
\pi_{t-1}^{\text {core }}\end{array}$ & $y_{t}-y^{*}$ & $\Delta e_{t-1} / \Delta e_{t}$ & $\pi_{t}^{i m p}$ & $\pi_{t}^{o i l}$ & D1 & D2 & SE & $\operatorname{LM}(1)$ & Z & W \\
\hline & & 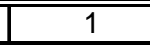 & 2 & 3 & 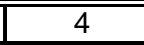 & 5 & $\overline{6}$ & 7 & 8 & 9 & 10 & 11 & 12 & 13 & 14 \\
\hline Japan & BL & $\begin{array}{c}0.142 \\
(0.296) \\
\end{array}$ & & $\begin{array}{c}0.715 \\
(0.000) \\
\end{array}$ & $\begin{array}{l}(-) 0.08 \\
(0.596) \\
\end{array}$ & $\begin{array}{c}0.141 \\
(0.103) \\
\end{array}$ & \begin{tabular}{|l|}
0.0212 \\
$(0.192)$ \\
\end{tabular} & & & & $\begin{array}{l}(-) 0.29 \\
(0.134) \\
\end{array}$ & 0.464 & 0.188 & $5.365(5)$ & $10.779(4)$ \\
\hline \multirow[t]{2}{*}{ (1993-2005) } & FL-ARIMA & $\begin{array}{c}0.132 \\
(0.278) \\
\end{array}$ & $\begin{array}{c}0.68 \\
(0.000) \\
\end{array}$ & & & $\begin{array}{l}0.146 \\
(0.07) \\
\end{array}$ & \begin{tabular}{|c|}
0.021 \\
$(0.164)$ \\
\end{tabular} & & & & $\begin{array}{l}(-) 0.23 \\
(0.198) \\
\end{array}$ & 0.438 & 2.784 & $5.919(6)$ & $10.67(4)$ \\
\hline & FL-Core & $\begin{array}{c}0.114 \\
(0.412) \\
\end{array}$ & $\begin{array}{c}0.643 \\
(0.000) \\
\end{array}$ & & & $\begin{array}{c}0.166 \\
(0.059) \\
\end{array}$ & \begin{tabular}{|c|}
0.018 \\
$(0.248)$ \\
\end{tabular} & & & & $\begin{array}{l}(-) 0.26 \\
(0.204) \\
\end{array}$ & 0.463 & 0.327 & $7.667(5)$ & $12.12(4)$ \\
\hline Korea & BL-IV & $\begin{array}{c}0.52 \\
(0.29) \\
\end{array}$ & & $\begin{array}{c}0.64 \\
(0.000) \\
\end{array}$ & & $\begin{array}{l}0.283 \\
(0.04) \\
\end{array}$ & $\begin{array}{l}0.091 \\
(0.02) \\
\end{array}$ & & & $\begin{array}{c}4.43 \\
(0.037) \\
\end{array}$ & & 2.3 & 2.55 & $9.7(3)$ & NA \\
\hline \multirow[t]{2}{*}{ (1997-2005) } & FL-ARIMA & $\begin{array}{c}0.52 \\
(0.26)\end{array}$ & $\begin{array}{c}0.63 \\
(0.000)\end{array}$ & & & $\begin{array}{l}0.216 \\
(0.08)\end{array}$ & $\begin{array}{c}0.091 \\
(0.015)\end{array}$ & & & $\begin{array}{c}4.16 \\
(0.036)\end{array}$ & & 2.14 & 1.80 & $10.13(3)$ & NA \\
\hline & FL-Core & $\begin{array}{c}0.51 \\
(0.32) \\
\end{array}$ & $\begin{array}{c}0.65 \\
(0.000) \\
\end{array}$ & & & $\begin{array}{l}0.316 \\
(0.05) \\
\end{array}$ & $\begin{array}{c}0.09 \\
(0.03) \\
\end{array}$ & & & $\begin{array}{c}4.54 \\
(0.04) \\
\end{array}$ & & 2.4 & 1.66 & $3.29(3)$ & NA \\
\hline Hong Kong & BL-IV & $\begin{array}{l}0.051 \\
(0.74)\end{array}$ & & $\begin{array}{c}0.921 \\
(0.000)\end{array}$ & $\begin{array}{c}(-) 0.029 \\
(0.866)\end{array}$ & $\begin{array}{c}0.131 \\
(0.152) \\
\end{array}$ & & $\begin{array}{c}0.169 \\
(0.003) \\
\end{array}$ & & & & 0.980 & 5.64 & $0.384(1)$ & $10.33(5)$ \\
\hline \multirow[t]{2}{*}{ (1993-2005) } & FL-ARIMA & $\begin{array}{c}0.121 \\
(0.457) \\
\end{array}$ & $\begin{array}{c}0.864 \\
(0.000) \\
\end{array}$ & & & $\begin{array}{c}0.142 \\
(0.089) \\
\end{array}$ & & $\begin{array}{c}0.178 \\
(0.001) \\
\end{array}$ & & & & 1.038 & 0.49 & $0.279(2)$ & $10.29(4)$ \\
\hline & FL-Core & $\begin{array}{c}0.212 \\
(0.352)\end{array}$ & $\begin{array}{c}0.129 \\
(0.844)\end{array}$ & & $\begin{array}{l}0.685 \\
(0.25)\end{array}$ & $\begin{array}{c}0.245 \\
(0.093)\end{array}$ & & $\begin{array}{c}0.235 \\
(0.086)\end{array}$ & & & & 1.445 & 0.12 & $0.850(1)$ & $0.35(5)$ \\
\hline Singapore & BL-IV & $\begin{array}{c}0.076 \\
(0.456)\end{array}$ & & $\begin{array}{c}0.758 \\
(0.000) \\
\end{array}$ & & $\begin{array}{c}0.03 \\
(0.164)\end{array}$ & & & $\begin{array}{c}0.006 \\
(0.051) \\
\end{array}$ & & & 0.453 & 5.87 & $6.005(3)$ & NA \\
\hline \multirow[t]{2}{*}{$(1997-2005)$} & FL-ARIMA & $\begin{array}{l}0.047 \\
(0.63)\end{array}$ & $\begin{array}{c}0.724 \\
(0.000)\end{array}$ & & & $\begin{array}{l}0.0316 \\
(0.207)\end{array}$ & & & $\begin{array}{c}0.008 \\
(0.039)\end{array}$ & & & 0.404 & 3.48 & $3.535(3)$ & NA \\
\hline & FL-Core & $\begin{array}{c}0.08 \\
(0.44)\end{array}$ & $\begin{array}{c}0.768 \\
(0.000)\end{array}$ & & & $\begin{array}{c}0.03 \\
(0.263)\end{array}$ & & & $\begin{array}{c}0.006 \\
(0.084)\end{array}$ & & & 0.449 & 4.63 & $6.896(3)$ & NA \\
\hline
\end{tabular}

Notes:

1. The notation is as follows: $\pi_{\mathrm{t}}$ - inflation at period $\mathrm{t} ; \pi_{\mathrm{t}+4}^{\mathrm{e}}$ - forward-looking 4-quarter ahead expectation of inflation; $\pi_{\mathrm{t}}^{\text {core }}$ - core inflation; $\mathrm{y}_{\mathrm{t}}-\mathrm{y}^{*}-$ output gap; $\Delta \mathrm{e}_{\mathrm{t}-1}=$ log (e)- $\log \left(e_{t-1}\right)$ where e represents the exchange rate of each currency against the dollar; $\pi_{t}^{\text {imp }}$ - import inflation; $\pi_{t}{ }^{\text {inf }}$ - oil inflation; D1 represents the dummy for spikes in inflation for the period 1998Q1-1998Q4 in the case of Korea; D2 represents the dummy to account for the period of deflation in the case of Japan.

2. The values in parenthesis denote the p-values for columns 1-10 and degrees of freedom for columns 12-14.

3. $\mathrm{Z}$ is the test for over identifying restrictions, $\mathrm{W}$ is the Wald test for structural change and LM (1) is the Lagrange Multiplier test for first order auto-correlation.

4. $\mathrm{Z}, \mathrm{W}$ and LM test statistics indicate that the null hypothesis not rejected at the $1 \%$ level of significance.

5. $\mathrm{SE}$ is the equation standard error 
Table 7: Estimation Results for the Developing Asian Countries

\begin{tabular}{|c|c|c|c|c|c|c|c|c|c|c|c|c|c|c|}
\hline Country & & constant & \begin{tabular}{|ll}
$\pi_{t+4}^{e}$ & $\pi_{t}^{\text {core }}$ \\
or
\end{tabular} & $\pi_{t-1}$ & $y_{t}-y^{*}$ & $\Delta e_{t-1} / \Delta e_{t}$ & $\pi_{t}^{\text {food }}$ & $x$ & $f p i$ & raind & SE & $\operatorname{LM}(1)$ & $z$ & W \\
\hline & & 1 & 2 & 3 & 4 & 5 & 6 & 7 & 8 & 9 & 10 & 11 & 12 & 13 \\
\hline Phillipines & $B L$ & $\begin{array}{c}0.476 \\
(0.394) \\
\end{array}$ & & $\begin{array}{l}0.9459 \\
(0.000) \\
\end{array}$ & $\begin{array}{c}0.06 \\
(0.112) \\
\end{array}$ & $\begin{array}{c}0.078 \\
(0.143) \\
\end{array}$ & & & $\begin{array}{c}(-) 0.125 \\
(0.007) \\
\end{array}$ & & 1.308 & 5.69 & $3.579(7)$ & 7.193(5) \\
\hline$(1992-2005)$ & FL-ARIMA & $\begin{array}{c}0.404 \\
(0.677) \\
\end{array}$ & $\begin{array}{l}-0.152 \\
(0.695) \\
\end{array}$ & & $\begin{array}{c}0.052 \\
(0.148) \\
\end{array}$ & $\begin{array}{c}0.063 \\
(0.192) \\
\end{array}$ & & & \begin{tabular}{|c|}
-0.101 \\
$(0.030)$ \\
\end{tabular} & & 1.258 & 0.07 & $3.308(7)$ & 7.16(6) \\
\hline & FL-Core & $\begin{array}{l}1.1525 \\
(0.045) \\
\end{array}$ & $\begin{array}{l}0.8038 \\
(0.000) \\
\end{array}$ & & $\begin{array}{l}0.046 \\
(0.23) \\
\end{array}$ & $\begin{array}{c}0.082 \\
(0.123) \\
\end{array}$ & & & $\begin{array}{c}(-) 0.070 \\
(0.126) \\
\end{array}$ & & 1.330 & 3.08 & $3.157(7)$ & $12.454(5)$ \\
\hline Thailand & BL-IV & $\begin{array}{c}0.787 \\
(0.294) \\
\end{array}$ & & $\begin{array}{c}0.936 \\
(0.000) \\
\end{array}$ & $\begin{array}{c}0.001 \\
(0.196) \\
\end{array}$ & $\begin{array}{c}0.226 \\
(0.004) \\
\end{array}$ & $\begin{array}{c}0.263 \\
(0.012) \\
\end{array}$ & & & & 0.588 & 3.260 & $0.849(2)$ & NA \\
\hline (2001-2005) & FL-ARIMA & $\begin{array}{c}0.025 \\
(0.542) \\
\end{array}$ & $\begin{array}{c}0.872 \\
(0.000) \\
\end{array}$ & & $\begin{array}{c}0.024 \\
(0.174) \\
\end{array}$ & $\begin{array}{c}0.143 \\
(0.054) \\
\end{array}$ & $\begin{array}{c}0.169 \\
(0.077) \\
\end{array}$ & & & & 0.423 & 2.165 & $1.239(5)$ & NA \\
\hline & FL-Core & $\begin{array}{c}0.045 \\
(0.245) \\
\end{array}$ & $\begin{array}{c}0.645 \\
(0.000) \\
\end{array}$ & & $\begin{array}{l}0.045 \\
(0.17) \\
\end{array}$ & $\begin{array}{c}0.265 \\
(0.052) \\
\end{array}$ & $\begin{array}{c}0.256 \\
(0.055) \\
\end{array}$ & & & & 0.543 & 2.761 & $2.412(3)$ & NA \\
\hline China & BL-IV & $\begin{array}{c}0.09 \\
(0.756) \\
\end{array}$ & & $\begin{array}{c}0.186 \\
(0.223) \\
\end{array}$ & $\begin{array}{c}0.248 \\
(0.086) \\
\end{array}$ & $\begin{array}{c}0.225 \\
(0.062) \\
\end{array}$ & $\begin{array}{c}0.286 \\
(0.000) \\
\end{array}$ & $\begin{array}{c}0.065 \\
(0.058) \\
\end{array}$ & & & 0.410 & 0.980 & $0.073(1)$ & NA \\
\hline$(2000-2005)$ & FL-ARIMA & $\begin{array}{l}0.146 \\
(0.56)\end{array}$ & $\begin{array}{l}0.154 \\
(0.21)\end{array}$ & & $\begin{array}{l}0.262 \\
(0.05)\end{array}$ & $\begin{array}{c}0.224 \\
(0.056)\end{array}$ & $\begin{array}{c}0.289 \\
(0.000)\end{array}$ & $\begin{array}{c}0.065 \\
(0.052)\end{array}$ & & & 0.397 & 0.900 & $0.032(1)$ & NA \\
\hline & FL-Core & $\begin{array}{c}0.001 \\
(0.997)\end{array}$ & $\begin{array}{c}0.208 \\
(0.007)\end{array}$ & & $\begin{array}{c}0.115 \\
(0.029)\end{array}$ & $\begin{array}{c}0.085 \\
(0.058)\end{array}$ & $\begin{array}{c}0.301 \\
(0.000)\end{array}$ & $\begin{array}{c}0.028 \\
(0.066)\end{array}$ & & & 0.229 & 0.913 & & NA \\
\hline India & BL-IV & $\begin{array}{l}0.124 \\
(0.9)\end{array}$ & & $\begin{array}{c}0.743 \\
(0.000)\end{array}$ & $\begin{array}{c}0.108 \\
(0.239)\end{array}$ & $\begin{array}{c}0.345 \\
(0.125)\end{array}$ & & & & $\begin{array}{l}1.419 \\
(0.17)\end{array}$ & 2.254 & 4.796 & $5.449(4)$ & NA \\
\hline$(1996-2005)$ & FL-ARIMA & $\begin{array}{l}0.095 \\
(0.93)\end{array}$ & $\begin{array}{c}0.74 \\
(0.000)\end{array}$ & & $\begin{array}{c}0.145 \\
(0.198)\end{array}$ & $\begin{array}{c}0.267 \\
(0.248)\end{array}$ & & & & $\begin{array}{c}1.485 \\
(0.196)\end{array}$ & 2.375 & 4.245 & $6.075(4)$ & NA \\
\hline & FL-Core & $\begin{array}{l}0.584 \\
(0.57)\end{array}$ & $\begin{array}{c}0.613 \\
(0.000)\end{array}$ & & $\begin{array}{c}0.152 \\
(0.108)\end{array}$ & $\begin{array}{c}0.457 \\
(0.065)\end{array}$ & & & & $\begin{array}{c}1.846 \\
(0.093)\end{array}$ & 2.378 & 3.961 & $6.03(4)$ & NA \\
\hline
\end{tabular}

Notes:

1. The notation is as follows: $\pi_{\mathrm{t}}$ - inflation at period $\mathrm{t} ; \pi_{\mathrm{t}+4}^{\mathrm{e}}$ - forward-looking 4-quarter ahead expectation of inflation; $\pi_{\mathrm{t}}^{\text {core }}$ - core inflation; $\mathrm{y}_{\mathrm{t}}-\mathrm{y}^{*}-$ output gap; $\Delta \mathrm{e}_{\mathrm{t}-1}=$ log (e)-log $\left(\mathrm{e}_{\mathrm{t}-1}\right)$ where e represents the exchange rate of each currency against the dollar; $\pi_{\mathrm{t}}^{\text {food }}$ - food inflation; $x_{\mathrm{t}}$ - productivity; fpi $i_{t}$ - food production index; raind $\mathrm{f}_{t}$ - dummy created for deviation of actual rainfall from the average.

2. The values in parenthesis denote the p-values for columns 1-10 and degrees of freedom for columns 12-14

3. $\mathrm{Z}$ is the test for over identifying restrictions, $\mathrm{W}$ is the Wald test for structural change and LM (1) is the Lagrange Multiplier test for first order auto-correlation.

4. $\mathrm{Z}, \mathrm{W}$ and LM test statistics indicate that the null hypothesis not rejected at the $1 \%$ level of significance.

5. $\mathrm{SE}$ is the equation standard error.

6. The equation for Thailand includes the real money gap instead of output gap since the latter was not statistically significant. 
Table 8: Summary of Significant Variables in the Phillips Curve

\begin{tabular}{|c|c|c|c|c|c|c|}
\hline & & & \multicolumn{2}{|c|}{ Demand Side factors } & \multicolumn{2}{|c|}{ Supply Side factors } \\
\hline & & & $\begin{array}{l}D_{t} \\
\text { (Domestic) } \\
\end{array}$ & $\begin{array}{c}X_{t} \\
\text { (External) }\end{array}$ & $\begin{array}{c}Z_{t} \\
\text { (Domestic) } \\
\end{array}$ & $\begin{array}{c}T_{t} \\
\text { (External) }\end{array}$ \\
\hline \multicolumn{7}{|c|}{ Developed Countries } \\
\hline Japan & $\pi_{t-1}$ & $\pi_{t+4}^{e}, \pi_{t}^{\text {core }}$ & Output Gap & $\begin{array}{l}\text { Exchange } \\
\text { rate }\end{array}$ & & \\
\hline Korea & $\pi_{t-1}$ & $\pi_{t+4}^{e}, \pi_{t}^{\text {core }}$ & Output Gap & \begin{tabular}{|l} 
Exchange \\
rate
\end{tabular} & & \\
\hline Hong Kong & $\pi_{t-1}$ & $\pi_{t+4}^{e}$ & Output Gap & $\begin{array}{l}\text { Import } \\
\text { Inflation }\end{array}$ & & \\
\hline Singapore & $\pi_{t-1}$ & $\pi_{t+4}^{e}, \pi_{t}^{\text {core }}$ & Output Gap & & & Oil inflation \\
\hline \multicolumn{7}{|c|}{ Developing Countries } \\
\hline Philippines & $\pi_{t-1}$ & $\pi_{t}^{\text {core }}$ & Output Gap & $\begin{array}{l}\text { Exchange } \\
\text { rate (growth } \\
\text { rate) }\end{array}$ & $\begin{array}{l}\text { Food Production } \\
\text { Index (growth } \\
\text { rate) }\end{array}$ & \\
\hline Thailand & $\pi_{t-1}$ & $\pi_{t+4}^{e}, \pi_{t}^{\text {core }}$ & $\begin{array}{l}\text { Real money } \\
\text { Gap }\end{array}$ & $\begin{array}{l}\text { Exchange } \\
\text { rate (growth } \\
\text { rate) }\end{array}$ & Food Inflation & \\
\hline China & & $\pi_{t}^{\text {core }}$ & Output Gap & $\begin{array}{l}\text { Exchange } \\
\text { rate (growth } \\
\text { rate) }\end{array}$ & $\begin{array}{l}\text { Food Inflation, } \\
\text { Productivity gap }\end{array}$ & \\
\hline India & $\pi_{t-1}$ & $\pi_{t+4}^{e}, \pi_{t}^{\text {core }}$ & Output Gap & $\begin{array}{l}\text { Exchange } \\
\text { rate (growth } \\
\text { rate) }\end{array}$ & $\begin{array}{l}\text { Deviation from } \\
\text { average rainfall }\end{array}$ & \\
\hline
\end{tabular}


Figure 1: Inflation - Output gap Trade-off for the Developed Asian countries

Japan

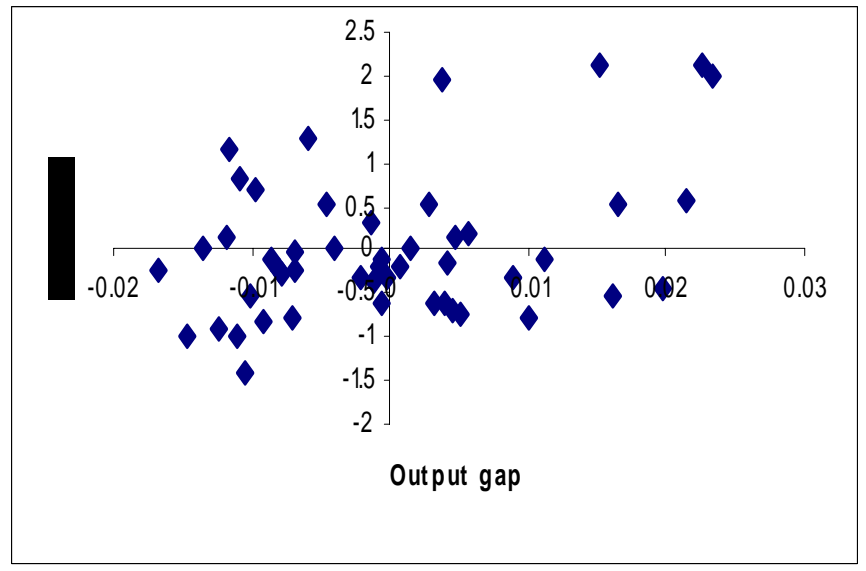

Singapore

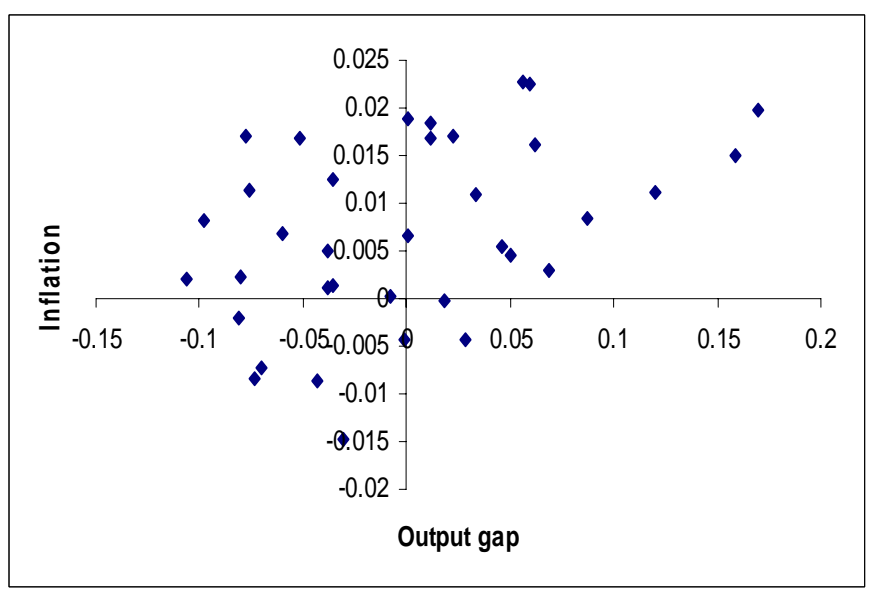

Korea

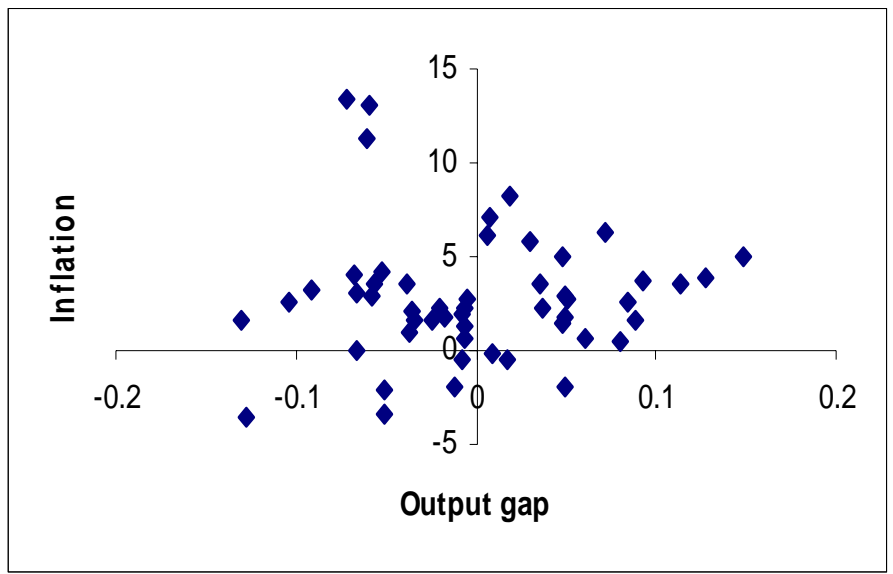

Hong Kong

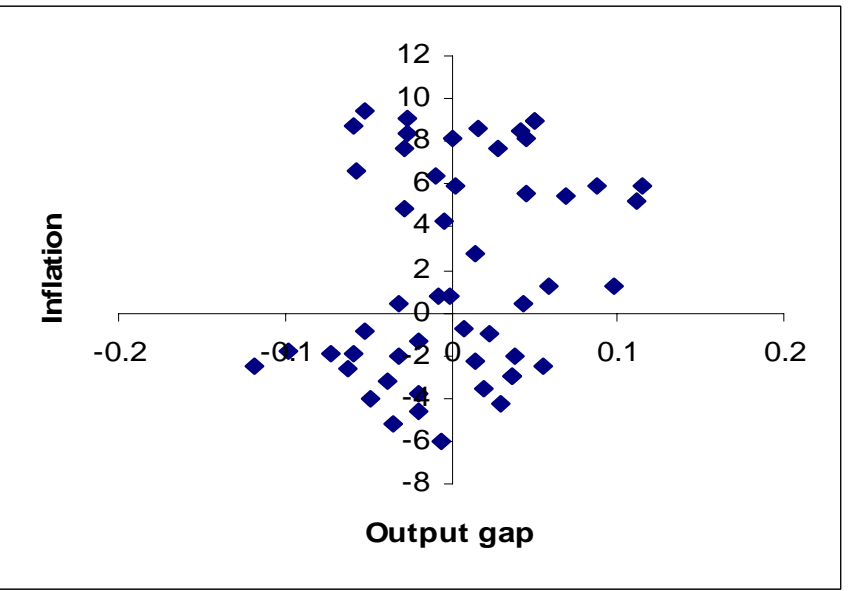


Figure 2: Inflation - Output gap Trade-off for the Developing Asian countries

Philippines

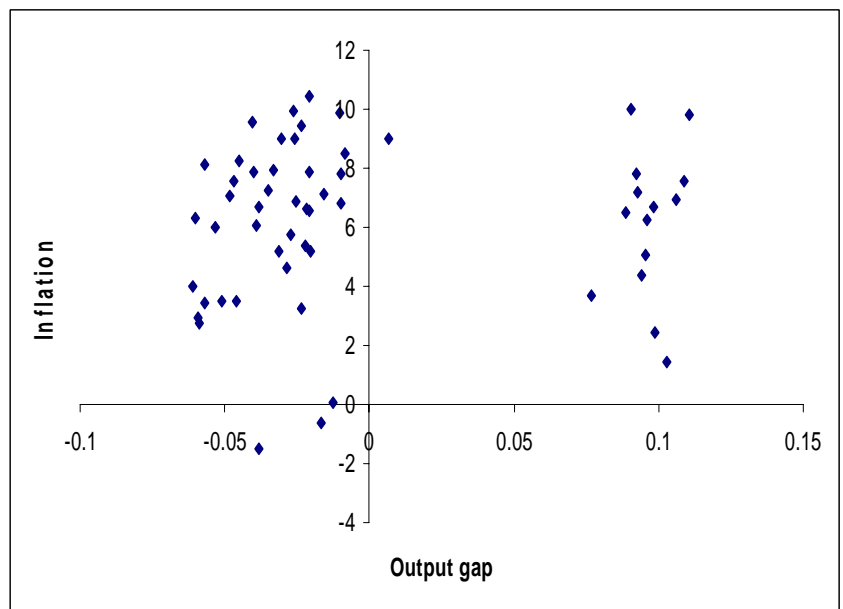

China

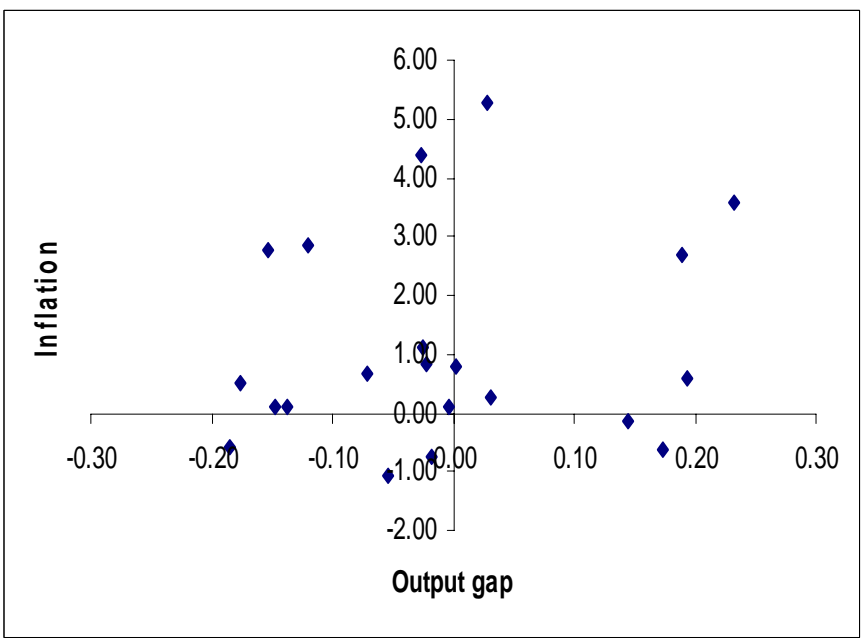

Thailand

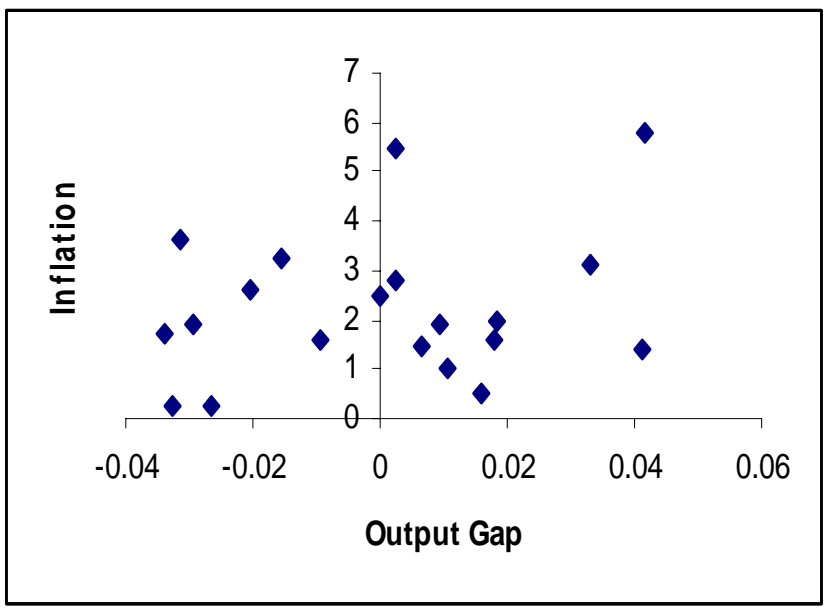

India

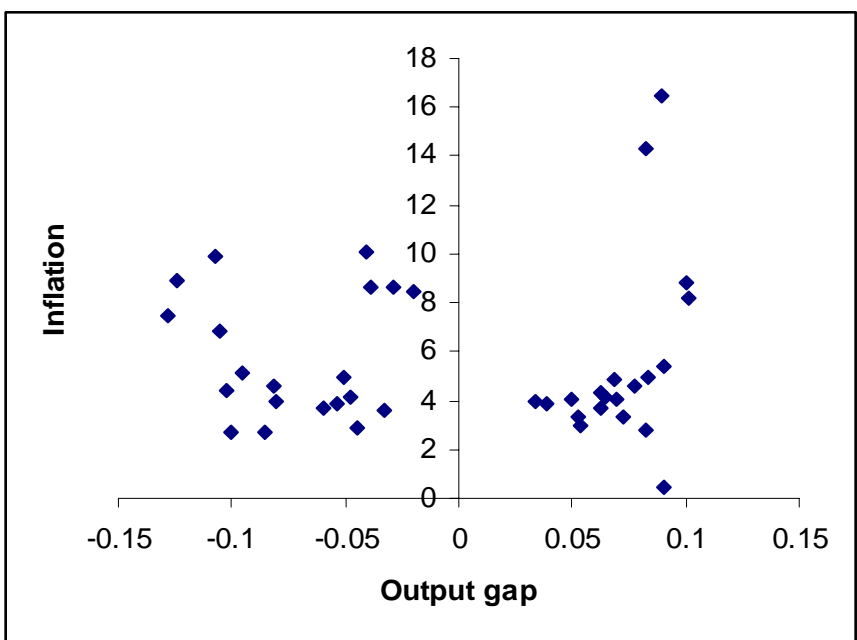

